\title{
Perbandingan Efek Anestesi Spinal dengan Anestesi Umum terhadap Kejadian Hipotensi dan Nilai APGAR Bayi pada Seksio Sesarea
}

\author{
Lasmaria Flora, ${ }^{1}$ Ike Sri Redjeki, ${ }^{2}$ A. Himendra Wargahadibrata ${ }^{2}$ \\ ${ }^{1}$ Bagian Anestesi RSUD Bangkinang Kab. Kampar Riau, ${ }^{2}$ Departemen Anestesiologi dan Terapi \\ Intensif Fakultas Kedokteran Universitas Padjadjaran/Rumah Sakit Dr. Hasan Sadikin Bandung
}

\begin{abstract}
Abstrak
Teknik anestesi spinal atau anestesi umum pada seksio sesarea menyebabkan penurunan tekanan darah berbeda, demikian pula nilai APGAR bayi. Tujuan penelitian ini untuk mengetahui kejadian hipotensi, nilai APGAR 1 menit dan 5 menit antara tindakan anestesi spinal dan anestesi umum. Penelitian dilakukan dengan cara randomized cross sectional pada 70 pasien di Rumah Sakit Dr. Hasan Sadikin Bandung pada FebruariMaret 2011. Setelah dilakukan randomisasi, pasien dibagi dalam dua kelompok, yaitu kelompok I (anestesi spinal) dan kelompok II (anestesi umum). Data kejadian hipotensi dianalisis dengan uji chi-kuadrat, untuk nilai APGAR menggunakan Uji Mann-Whitney. Hasil penelitian menunjukkan kejadian hipotensi 57,1\% pada kelompok anestesi spinal, sedangkan kelompok anestesi umum hanya 5,7\% $(\mathrm{p}<0,001)$. Nilai APGAR ratarata 1 menit pada kelompok anestesi spinal 8, sedangkan pada kelompok anestesi umum 7,06. Berdasarkan Uji Mann Whitney didapatkan $p<0,001$. Nilai APGAR rata-rata 5 menit pada kelompok anestesi spinal 9,71, sedangkan pada kelompok anestesi umum 9,31 ( $\mathrm{p}=0,015)$. Simpulan penelitian ini adalah angka kejadian hipotensi lebih tinggi pada anestesi spinal daripada anestesi umum. Nilai APGAR bayi 1 menit dan 5 menit lebih tinggi pada anestesi spinal dibandingkan dengan anestesi umum.
\end{abstract}

Kata kunci: Anestesi spinal, anestesi umum, hipotensi, nilai APGAR, seksio sesarea

\section{Comparison of Spinal Anesthesia and General Anesthesia Effects on Hypotension and APGAR Scoring Values of Caesarean Section Babies}

\begin{abstract}
Spinal anesthesia and general anesthesia techniques in cesarean section lead to different decreased blood pressure and APGAR score. The purpose of this study was to identify the differences in hypotension as well as, 1 minute and 5 minutes APGAR scores in spinal anesthesia and general anesthesia. A randomized cross-sectional study was conducted on 70 patients at Dr. Hasan Sadikin General Hospital Bandung during the period of February to March 2011. Patients were divided into two groups: group I (spinal anesthesia) and group II (general anesthesia). The data on hypotension was analyzed with chi square test while, the APGAR scores were analyzed using Mann Whitney test. The results of the study showed that there were $57.1 \%$ cases of hypotension in the spinal anesthesia group whereas the percentage in the group of general anesthesia group was only $5.7 \%(\mathrm{p}<0.001)$. The mean for 1 minute APGAR score in the spinal anesthesia group was 8 whereas the general anesthesia group gave 7.06. The Mann Whitney showed that $p<0.001$. The mean for 5 minute APGAR score or the spinal anesthesia group was 9.71, where as the mean for the general anesthesia group was 9.31 with the. Mann Whitney test result of $p=0.015$. The conclusion of this study is the hypotension incidence is higher in spinal anesthesia compared to general anesthesia. The 1 minute and 5 minute APGAR scores are higher for spinal anesthesia compared to general anesthesia.
\end{abstract}

Key words: APGAR score, caesarean section, general anesthesia, hypotension, spinal anesthesia

Korespondensi: Lasmaria Flora, dr., SpAn. M. Kes, Bagian Anestesi RSUD Bangkinang, Jl. Abdurahman Saleh No. 1 Bangkinang, Kab. Kampar Riau, Telp (0762) 323330, Mobile 081365665184, Email lasmaria_flora@yahoo.com 


\section{Pendahuluan}

Pembedahan cesar sering dilakukan sebagai operasi elektif maupun emergensi. ${ }^{1}$ Indikasi yang paling umum adalah kegagalan kemajuan pembukaan jalan lahir, gawatjanin, disproporsi sefalopelvik, letak janin abnormal, prematur, dan juga riwayat seksio sesarea sebelumnya. Pilihan teknikanestesia yang digunakan adalah anestesia regional atau umum yang memiliki keuntungan dan juga kerugian masing-masing. Pilihan anestesia bergantung pada indikasi operasi, derajat urgensi (keadaan mendesak), keadaan ibu, dan keinginan pasien..$^{1-3}$

Secara internasional, Obstetric Anaesthesia Guidelines merekomendasikan teknikanestesia spinal ataupun epidural dibandingkan dengan anestesia umum untuk sebagian besar seksio sesarea. Di Amerika Serikat pada tahun 1992, anestesi spinal digunakan lebih dari $80 \%$ pada operasi sesar, tanpa menghiraukan indikasi. ${ }^{1}$ Alasan utama direkomendasikannya anestesia regional pada saat operasi sesar adalah risiko terjadinya kegagalan intubasi endotrakea serta kemungkinan terjadi aspirasi bila dilakukan dengan anestesia umum. ${ }^{3}$

Anestesia umum seringkali dihubungkan dengan kejadian depresi neonatus yang kerap memerlukan tindakan resusitasi. Keuntungan anestesia umum adalah prosedur kerja lebih cepat sehingga sering dilakukan pada kasuskasus dengan kecepatan waktu menjadi faktor utama, penurunan insidensi hipotensi dan juga ketidakstabilan kardiovaskular, jalan napas, serta ventilasi tetap terjaga dan terkontrol. ${ }^{4-7}$

Anestesia regional memberikan beberapa keuntungan, antara lain adalah ibu akan tetap terbangun, mengurangi kemungkinan terjadi aspirasi dan menghindari depresi neonatus. ${ }^{4}$ Efek samping hipotensi dan juga bradikardia merupakan proses perubahan fisiologis yang paling banyak terjadi akibat tindakan anestesia spinal. Anestesia spinal dapat mengakibatkan penurunan tajam pada tekanan darah ibu yang akan memengaruhi keadaan ibu dan bayi., ${ }^{4,7}$

Hipotensi merupakan penurunan tekanan darah sistol lebih dari 20-30\% dibandingkan dengan pengukuran dasar atau tekanan darah sistol $<100 \mathrm{mmHg}$. Kejadian hipotensi dapat menyebabkan gangguan perfusi uteroplasenta sehingga mengakibatkan hipoksia dan asidosis fetus serta depresi neonatus. Hipotensi yang berat pada ibu dapat menyebabkan penurunan kesadaran, aspirasi paru, henti napas, dan juga henti jantung. ${ }^{8}$

Anestesia spinal mengakibatkan hipotensi melalui blokade saraf simpatis yang berfungsi mengatur tonus otot polos pembuluh darah. Blokade serabut saraf simpatis preganglionik yang menyebabkan vasodilatasi vena, sehingga terjadi pergeseran volume darah terutama ke bagian splanik dan juga ekstremitas bawah sehingga akan menurunkan aliran darah balik ke jantung. Selain itu, juga terjadi penurunan resistensi pembuluh darah pre dan postkapilar arteri. $^{8}$

Berbagai cara digunakan untuk mencegah serta menangani hipotensi yang terjadi pada seksio sesarea, antara lain posisi uterus miring ke kiri (minimum $15^{\circ}$ ) dengan cara mengganjal pelvis atau memiringkan meja, posisi sedikit head up setelah penyuntikan obat anestesia lokal hiperbarik, pemberian cairan kristaloid atau koloid sebelum tindakan anestesia spinal, vasopresor (efedrin, penilefrin, atau dopamin), obat yang paling sering dipergunakan adalah efedrin, biasanya diberikan secara intravena dengan dosis 5-10 mg. Cara lain yang dapat dilakukan untuk menangani hipotensi adalah dengan cara elevasi tungkai bawah dan atau membungkusnya (mempergunakan stocking). ${ }^{8}$

Berdasarkan suatu penelitian didapatkan bahwa penurunan tekanan darah rata-rata dari 124/72 mmHg menjadi 67/38 mmHg pada ibu yang diposisikan terlentang setelah dilakukan tindakan anestesia spinal pada seksio sesarea, sedangkan yang diposisikan miring, tekanan darah rata-rata 100/60 mmHg. Perubahan hemodinamik terjadi karena blokade simpatis vasomotor yang diperberat penekanan aorta dan juga vena kava inferior oleh uterus yang membesar pada saat posisi pasien terlentang. Penurunan tekanan darah ibu yang signifikan akan membahayakan ibu serta janin, apabila penurunan tekanan darah dan curah jantung tersebut tidak segera diketahui dan ditangani. Hipotensi yang terjadi tersebut menurunkan 
nilai APGAR. Hipotensi dengan periode waktu yang pendek, yaitu tidak lebih dari dua menit, dapat meminimalkan asidosis bayi serta tidak memengaruhi efek neurobehavioral bayi. ${ }^{7}$

Nilai APGAR, mengidentifikasi bayi-bayi yang memerlukan tindakan resusitasi dan juga menindaklanjuti perkembangan lebih lanjut pada menit-menit pertama kehidupan. Nilai APGAR 1 menit memberi gambaran seberapa baik bayi dapat melakukan toleransi terhadap proses kelahiran, serta menunjukkan bahwa bayi yang baru lahir membutuhkan perhatian medis lebih lanjut (tindakan resusitasi), tetapi belum tentu hal tersebutmengindikasikan akan terjadi masalah jangka panjang, khususnya jika terjadi peningkatan nilai pada menit kelima. Nilai APGAR 5 menit memberikan penilaian seberapa jauh bayi dapat berespons terhadap tindakan resusitasi yang diberikan dan juga merupakan prediksi yang lebih tepat tentang kemungkinan kematian bayi dan juga sekuele neurologik. ${ }^{1,7}$

Melahirkan bayi melalui bedah sesar sering dilakukan dengan teknik anestesia spinal akan tetapi beberapa kasus memerlukan anastesia umum, dengan keuntungan dan juga kerugian masing-masing. Teknik anestesi spinal maupun umum pada pembedahan sesar menyebabkan perubahan pada tekanan darah yang berbeda, demikian pula dengan nilai APGAR bayi. Nilai APGAR dipengaruhi oleh perfusi uteroplasenta serta transfer obat-obatan melalui plasenta, sehingga perlu dilakukan penelitian pengaruh teknik anestesia spinal serta umum terhadap kejadian hipotensi dan juga nilai APGAR bayi 1 menit serta 5 menit. Sampai saat ini belum terdapat penelitian yang dilakukan di Rumah SakitDr.HasanSadikin(RSHS) Bandungtentang perbandingan angka kejadian hipotensi dan juga nilai APGAR bayi pada tindakan anestesia spinal dengan anetesia umum, oleh karena itu peneliti tertarik untuk melakukan penelitian membandingkan efek anestesia spinal dengan anestesia umum pada seksio sesarea terhadap kejadian hipotensi dan juga nilai APGAR bayi 1 menit serta 5 menit. Penelitian ini bertujuan untuk menilai perbedaan kejadian hipotensi pada anestesi spinal dan anestesi umum pada ibu yang dilakukan seksio sesarea, menilai perbandingan efek anestesi spinal dan anestesi umum terhadap nilai APGAR 1 menit, dan juga menilai perbandingan efek anestesi spinal dan anestesi umum terhadap nilai APGAR 5 menit.

\section{Subjek dan Metode}

Metode penelitian ini adalah randomized cross sectional, dengan subjek adalah wanita hamil yang menjalani seksio sesarea di Rumah Sakit Dr. Hasan Sadikin Bandung (RSHS) pada Februari-Maret 2011, yang memenuhi kriteria inklusi, yaitu kehamilan aterm, status fisik American Society of Anesthesiologist (ASA) II, tinggi badan pasien $150-160 \mathrm{~cm}$, berusia $<40$ tahun, bodymassindex (BMI) $<40\left(\mathrm{~kg} / \mathrm{m}^{2}\right)$, serta mengeluarkan yang termasuk kriteria eksklusi, yaitu wanita hamil aterm dengan kehamilan gawat janin, perdarahan antepartum, gemeli, polihidramnion, kehamilan dengan bayi cacat kongenital, kehamilan intra uterine growth retardation, hipotensi (tekanan darah sistol $\leq 100 \mathrm{mmHg}$ ), diperkirakan kesulitan intubasi. Subjek dikeluarkan dari penelitian apabila anestesia spinal tidak bekerja (ditunggu $\geq 10$ menit) atau terjadi kesulitan intubasi.

Besar sampel ditentukan mempergunakan rumus perbedaan dua proporsi efektivitas dua tindakan, dan berdasarkan taraf kepercayaan ( $\alpha$ ) 95\% dengan besar uji kekuatan (power test) $80 \%$, sehingga dibutuhkan minimal 35 subjek untuk setiap kelompok dengan jumlah sampel pada kedua kelompok ialah 70 subjek. Pemilihan subjek dilakukan secara consecutive sampling, sedangkan alokasi subjek ke dalam perlakuan dilakukan dengan cara random blok permutasi. Setelah mendapatkan persetujuan dari Komite Etik Penelitian Kesehatan Rumah Sakit Dr. Hasan Sadikin/Fakultas Kedokteran Universitas Padjadjaran Bandung, pasien yang telah memenuhi kriteria inklusi dan juga tidak termasuk eksklusi serta diberikan penjelasan mengenai tindakan yang akan dilakukan dan menyetujui untuk ikut serta (informed consent) dilakukan randomisasi dengan menggunakan tabel bilangan random.

Kelompok I mendapatkan anestesia spinal sedangkan kelompok II mendapat anestesia umum. Pada semua pasien dilakukan penilaian 
bunyi jantung bayi, diukur tekanan darah, laju nadi, serta saturasi oksigen perifer prabedah. Pemasangan jalur vena dilakukan memakai kanula vena no. 18.

Kelompok I (anestesia spinal) diberikan preloading cairan Ringer laktat sebanyak 15 $\mathrm{mL} / \mathrm{kgBB}$, saat 15 menit sebelum penyuntikan spinal. Pasien diposisikan duduk, dilakukan identifikasi tempat penyuntikan, lalu dilakukan tindakan a dan juga antiseptik pada tempat yang akan disuntik. Jarum spinal berukuran 27 ditusukkan di garis tengah intervertebralis $\mathrm{L}_{3-4}$ sampai ke ruang intratekal. Setelah cairan serebrospinal keluar, disuntikkan bupivakain $0,5 \%$ hiperbarik sebanyak 2,5 mL. Setelah penyuntikan, posisi dikembalikan terlentang dengan bokong kanan diganjal bantal $30^{\circ}$ dan diberikan oksigen melalui kanul nasal 2-3 L/ menit. Tekanan darah sistol, diastol, laju nadi setelah penyuntikan obat spinal dicatat setiap menit selama 15 menit, serta setiap 3 menit sampai bayi lahir dengan mesin monitor Life Scope 14 Nihon Kohden. Kejadian hipotensi pertama kali dicatat.

Kelompok II (anestesia umum) diberikan cairan Ringer laktat sebanyak 1,5 mL/kgBB/ jam dikalikan dengan lamanya puasa, diberikan metoklopramid $10 \mathrm{mg} /$ i.v. serta ranitidin 50 $\mathrm{mg} /$ i.v. Pasien diberikan preoksigenasi dengan oksigen 100\% selama 3 menit, lalu diinduksi menggunakan propofol $2 \mathrm{mg} / \mathrm{kgBB} /$ i.v., setelah refleks bulu mata negatif (-), dilakukan sellick manuveur. Bersamaan dengan itu disuntikkan suksinilkolin 1,5 mg/kgBB/i.v. untuk fasilitas intubasi per oral mempergunakan ETT No. 6,5. Pemeliharaan anestesia dengan $\mathrm{N}_{2} \mathrm{O} 50 \%: \mathrm{O}_{2}$ $50 \%$, enfluran $1 \mathrm{MAC}$, dan atrakurium $0,5 \mathrm{mg} /$ $\mathrm{kgBB} /$ i.v. Setelah bayi lahir diberikan fentanil $1 \mu \mathrm{g} / \mathrm{kgBB} /$ i.v. $^{2-4,9-11}$

Tekanan darah sistol, diastol, laju nadi, dan saturasi oksigen perifer dicatat setiap menit selama 15 menit dan setiap 3 menit sampai bayi lahir. Kejadian hipotensi pertama kali dicatat. Pada kedua kelompok dilakukan pencatatan induction delivery interval (ID) serta uterine incision delivery interval (UD). Nilai APGAR bayi dicatat setelah bayi lahir yang meliputi 1 menit dan 5 menit, bila terjadi hipotensi pada kedua kelompok dapat diberikan efedrin 5 mg intravena. Jumlah efedrin yang diberikan dicatat. Apabila terjadi bradikardia, diberikan sulfas atropin 0,5 mg intravena.

Analisis statistika untuk membandingkan perbedaan kejadian hipotensi pertama kali mempergunakan uji chi-kuadrat, sedangkan untuk membandingkan tekanan darah ratarata (sistol dan diastol) serta laju nadi pada kedua kelompok dilakukan mempergunakan uji-t. Analisis untuk membandingkan median nilai APGAR bayi saat 1 menit dengan 5 menit mempergunakan Uji Mann-Whitney. Tingkat kepercayaan $(\alpha)$ 95\%, dianggap bermakna bila $\mathrm{p}<0,05$ serta sangat bermakna bila $\mathrm{p}<0,001$. Data disajikan dalam bentuk rata-rata (SD) dan dianalisis menggunakan program statistical product and servise solution (SPSS) 13,0 for Windows.

\section{Hasil}

Penelitian telah dilakukan terhadap 70 pasien seksio sesarea. Pasien dikelompokkan menjadi dua kelompok, yaitu kelompok anestesi spinal dan anestesi umum, setiap kelompokperlakuan terdiri atas 35 pasien. Berdasarkan pada hasil pengujian statistika dengan mempergunakan uji-t, menunjukkan hasil bahwa tidak terdapat perbedaan yang bermakna pada karakteristik subjek penelitian berdasarkan usia $(p=0,159)$ maupun BMI ( $p>0,05)$, sehingga homogenitas karakteristik pada kedua kelompok tersebut layak diperbandingkan. Insiden hipotensi yang pertama kali diukur saat penurunan tekanan darah sistol lebih dari 20\% dari baseline atau tekanan darah sistol di bawah $90 \mathrm{mmHg}$, maka berdasarkan uji statistika menggunakan chikuadrat didapatkan perbedaaan yang sangat bermakna $(p<0,001)$ pada kejadian hipotensi kelompok anestesia spinal bila dibandingkan dengan kelompok anestesi umum.

Nilai APGAR 5-7 (asfiksia ringan) pada kelompok anestesi spinal didapatkan sebanyak 7/35 bayi, sedangkan pada kelompok anestesi umum didapatkan lebih banyak yaitu 25/35 bayi. Nilai APGAR 8-10 (bayi normal/sehat) pada kelompok anestesia spinal didapatkan pada $28 / 35$ bayi, sedangkan pada kelompok 
Tabel 1 Karakteristik Subjek Penelitian

\begin{tabular}{|c|c|c|c|c|c|}
\hline \multirow{3}{*}{ Karakteristik } & \multicolumn{4}{|c|}{ Kelompok } & \multirow{3}{*}{ Nilai $\mathbf{p}$} \\
\hline & \multicolumn{2}{|c|}{ Spinal $(n=35)$} & \multicolumn{2}{|c|}{ Umum $(n=35)$} & \\
\hline & $\begin{array}{l}\text { Rata-rata } \\
\text { (SB) }\end{array}$ & $\begin{array}{c}\text { Median } \\
\text { (Rentang) }\end{array}$ & $\begin{array}{c}\text { Rata-rata } \\
\text { (SB) }\end{array}$ & $\begin{array}{c}\text { Median } \\
\text { (Rentang) }\end{array}$ & \\
\hline Usia (tahun) & $31,2(6,01)$ & $31(20-39)$ & $29,06(6,58)$ & $30(17-39)$ & 0,159 \\
\hline BMI $\left(\mathrm{kg} / \mathrm{m}^{2}\right)$ & $28,16(2,12)$ & $28,13(24,61-33,20)$ & $28,01(2,45)$ & $28,13(22,67-33,76)$ & 0,782 \\
\hline
\end{tabular}

Keterangan: nilai $\mathrm{p}$ berdasarkan uji-t, $\mathrm{p}<0,05$ bermakna

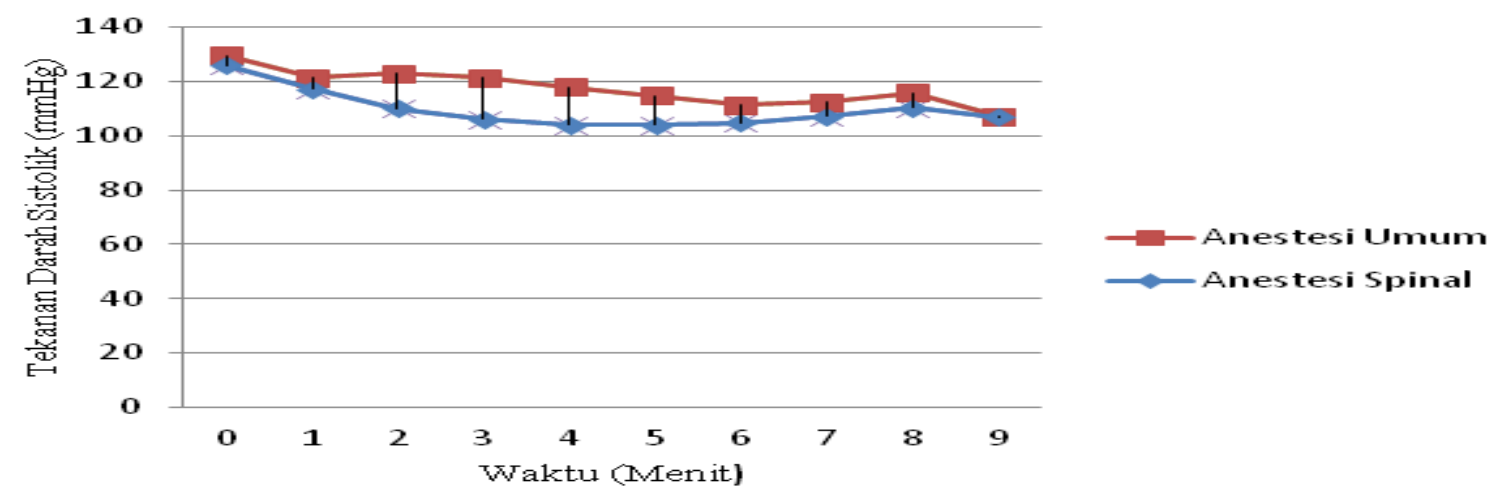

Gambar 1 Tekanan Darah Sistol Rata-rata (mmHg) dari Waktu ke Waktu pada Kelompok Anestesi Spinal dan Anestesi Umum

anestesia umum 10/35 bayi. Berdasarkan uji statistika terdapat perbedaan yang signifikan $(\mathrm{p}<0,001)$ terhadap nilai APGAR bayi 1 menit pada kelompok anestesia spinal dibandingkan dengan kelompok anestesia umum.

Nilai APGAR 5-7 (asfiksia ringan) pada kedua kelompok ini didapatkan dengan jumlah yang sama yaitu $1 / 35$ bayi. Nilai APGAR 8-10 (bayi sehat) pada kedua kelompok didapatkan

\section{Tabel 2 Kejadian Hipotensi Pertama Kali} pada Kedua Kelompok

\begin{tabular}{|c|c|c|c|}
\hline \multirow{3}{*}{$\begin{array}{l}\text { Kejadian } \\
\text { Hipotensi }\end{array}$} & \multicolumn{2}{|c|}{ Kelompok } & \multirow{3}{*}{ Nilai p } \\
\hline & $\begin{array}{c}\text { Spinal } \\
(n=35)\end{array}$ & $\begin{array}{l}\text { Umum } \\
(n=35)\end{array}$ & \\
\hline & $\mathbf{n}$ & $\mathbf{n}$ & \\
\hline Hipotensi & 20 & 2 & $<0,001$ \\
\hline $\begin{array}{l}\text { Tidak } \\
\text { hipotensi }\end{array}$ & 15 & 33 & \\
\hline
\end{tabular}

Keterangan: nilai $\mathrm{p}$ berdasarkan uji chi-kuadrat, $\mathrm{p}<0,05$ bermakna dengan jumlah yang sama pula yaitu masingmasing 34/35 bayi, dan tidak didapatkan satu orang bayipun memiliki nilai APGAR 1 menit dan 5 menit di bawah 5, sehingga tidak ada satu orang bayipun dengan kondisi asfiksia sedang dan juga asfiksia berat pada kedua kelompok. Berdasarkan uji statistika didapatkan bahwa tidak terdapat perbedaan yang bermakna nilai APGAR 5 menit berdasarkan kategori pada kedua kelompok $(\mathrm{p}=1)$.

Data hasil pengujian tekanan darah sistol, diastol, laju nadi, serta saturasi oksigen perifer yang diukur mulai sebelum tindakan anestesia lalu setiap 1 menit setelah tindakan anestesia sampai bayi lahir terlihat pada Tabel 5-8.

Analisis statistika dengan mempergunakan uji-t menunjukkan bahwa sebelum dilakukan tindakan anestesia tidak terdapat perbedaan tekanan darah sistol kedua kelompok sehingga dianggap homogen serta layak dibandingkan. Perbedaan penurunan tekanan darah diantara kelompok anestesia spinal dan umum mulai didapatkan pada saat menit kedua $(p=0,001)$. 
Tabel 3 Nilai APGAR 1 Menit berdasarkan Kategori

\begin{tabular}{lccc}
\hline \multirow{2}{*}{ Nilai Skoring } & \multicolumn{2}{c}{ Kelompok } & \\
\cline { 2 - 3 } & Spinal (n=35) & Umum (n=35) & Nilai p \\
\cline { 2 - 3 } & Jumlah & Jumlah & $<0,001$ \\
\hline 0-2 (asfiksia berat) & 0 & 0 & \\
3-4 (asfksia sedang) & 0 & 0 & \\
5-7 (asfiksia ringan) & 7 & 25 \\
8-10 (normal) & 28 & 10 \\
Median & 8 & 7 \\
Rentang & $5-9$ & $5-9$ \\
\hline
\end{tabular}

Keterangan: nilai $\mathrm{p}$ berdasarkan Uji Mann-Whitney, $\mathrm{p}<0,05$ bermakna

Walaupun terdapat penurunan tekanan darah pada kelompok anestesia spinal tetapi tidak didapatkan tekanan darah rata-rata di bawah $100 \mathrm{mmHg}$ karena nilai tersebut merupakan akibat pemberian efedrin 5-10 mg intravena pada pasien yang mengalami hipotensi (Tabel 5).

Berdasarkan uji statistika mempergunakan uji-t, terdapat perbedaan nilai tekanan darah diastol kedua kelompok mulai menit pertama $(\mathrm{p}<0,05$; Tabel 6).

Pada kedua kelompok menunjukkan tidak terdapat perbedaan laju nadi yang bermakna setelah tindakan antara anestesia spinal dan umum ( $p>0,05$; Tabel 6).

Saturasi oksigen perifer kelompok anestesi spinal memiliki rentang 95-100\%, sedangkan kelompok anestesia umum adalah 93-100\%. Berdasarkan hasil analisis statistik didapatkan perbedaan signifikan setelah menit kedua, tetapi tidak didapatkan desaturasi pada kedua kelompok (Tabel 8).

Hasil uji statistika menggunakan Uji MannWhitney tidak terdapat perbedaan UD interval antara kelompok anestesia spinal dan umum $(p=0,769)$. Berdasarkan pada hasil penelitian didapatkan induction delivery interval (ID) rata-rata pada kelompok anestesi spinal 16,89 menit dengan rentang 10-27 menit, sedangkan kelompok anestesia umum 6,14 menit dengan rentang waktu 4-9 menit. Penurunan tekanan darah yang terjadi ini (hipotensi) memerlukan penanggulangan dengan memberikan efedrin intravena baik pada kelompok anestesi spinal maupun umum. Pada penelitian ini didapatkan jumlah subjek yang mendapatkan efedrin pada kelompok anestesia spinal berjumlah 20/35 subjek, sedangkan pada kelompok anestesia

Tabel 4 Nilai APGAR 5 Menit berdasarkan Kategori

\begin{tabular}{lcccc}
\hline \multirow{2}{*}{ Nilai } & \multicolumn{2}{c}{ Kelompok } & \multirow{2}{*}{ Nilai p } \\
\cline { 2 - 3 } & Spinal (n=35) & Umum (n=35) & \\
\cline { 2 - 3 } & Jumlah & Jumlah & $\mathrm{p}=1$ \\
0-2 (asfiksia berat) & 0 & 0 & \\
3-4 (asfiksia sedang) & 0 & 0 & \\
5-7 (asfiksia ringan) & 1 & 1 & \\
8-10 (normal) & 34 & 34 & \\
Median & 10 & 9 & \\
Rentang & $7-10$ & $7-10$ & \\
\hline
\end{tabular}

Keterangan: nilai $p$ berdasarkan Uji Mann-Whitney, $p<0,05$ bermakna 
Tabel 5 Nilai Rata-rata dan Simpang Baku Tekanan Darah Sistol (mmHg)

\begin{tabular}{|c|c|c|c|c|c|}
\hline \multirow{3}{*}{ Menit } & \multicolumn{4}{|c|}{ Kelompok } & \multirow{3}{*}{ Nilai p } \\
\hline & \multicolumn{2}{|c|}{ Spinal $(n=35)$} & \multicolumn{2}{|c|}{ Umum $(n=35)$} & \\
\hline & Rata-rata & SB & Rata-rata & SB & \\
\hline 0 & 125,86 & 7,99 & 129,54 & 10,31 & 0,099 \\
\hline 1 & 117,23 & 13,69 & 121,43 & 10,95 & 0,161 \\
\hline 2 & 110,03 & 15,51 & 122,89 & 12,79 & 0,001 \\
\hline 3 & 106,03 & 15,78 & 121,34 & 11,79 & $<0,001$ \\
\hline 4 & 103,83 & 15,28 & 117,83 & 11,37 & $<0,001$ \\
\hline 5 & 103,94 & 14,64 & 114,63 & 11,02 & 0,002 \\
\hline 6 & 104,69 & 14,84 & 111,25 & 8,77 & 0,077 \\
\hline 7 & 107,03 & 11,82 & 112,33 & 10,76 & 0,142 \\
\hline 8 & 110,23 & 11,36 & 115,78 & 11,79 & 0,202 \\
\hline 9 & 106,83 & 12,45 & 107,00 & 12,45 & 0,985 \\
\hline
\end{tabular}

Keterangan: nilai $\mathrm{p}$ berdasarkan uji-t, $\mathrm{p}<0,05$ signifikan, $\mathrm{p}<0,001$ sangat bermakna, 0 : sebelum tindakan anestesi, 1 : satu menit setelah tindakan anestesi, 9: sembilan menit setelah tindakan anestesi

umum sebanyak $2 / 35$ orang.

\section{Pembahasan}

Perubahan fisiologi paling umum dan banyak terjadi akibat tindakan anestesia spinal adalah hipotensi (penurunan tekanan darah lebih dari 20\% dari tekanan baseline atau di bawah $90 \mathrm{mmHg}$ ). Hipotensi yang terjadi diakibatkan oleh dilatasi vena dan arteri. Blokade spinal yang terjadi dapat mengakibatkan penurunan tekanandarahyangdisebabkanolehpenurunan isi sekuncup, curah jantung, tekanan arteri, dan resistensi perifer sistemik. Tonus vasomotor

Tabel 6 Nilai Rata-rata dan Simpang Baku Tekanan Darah Diastol (mmHg)

\begin{tabular}{|c|c|c|c|c|c|}
\hline \multirow{3}{*}{ Menit } & \multicolumn{4}{|c|}{ Kelompok } & \multirow{3}{*}{ Nilai p } \\
\hline & \multicolumn{2}{|c|}{ Spinal $(n=35)$} & \multicolumn{2}{|c|}{ Umum $(n=35)$} & \\
\hline & Rata-rata & SB & Rata-rata & SB & \\
\hline 0 & 72,17 & 7,86 & 78,03 & 9,34 & 0,223 \\
\hline 1 & 66,11 & 11,55 & 74,60 & 9,85 & 0,017 \\
\hline 2 & 59,26 & 10,97 & 73,00 & 11,98 & $<0,001$ \\
\hline 3 & 55,00 & 12,12 & 72,20 & 9,51 & $<0,001$ \\
\hline 4 & 53,46 & 12,66 & 68,74 & 9,83 & $<0,001$ \\
\hline 5 & 54,57 & 12,93 & 66,20 & 9,45 & 0,002 \\
\hline 6 & 55,43 & 12,66 & 65,65 & 9,75 & 0,002 \\
\hline 7 & 56,89 & 10,79 & 64,88 & 8,04 & 0,091 \\
\hline 8 & 58,89 & 9,75 & 64,25 & 11,19 & 0,471 \\
\hline 9 & 56,74 & 11,02 & 64,00 & 4,24 & 0,365 \\
\hline
\end{tabular}

Keterangan: nilai $\mathrm{p}$ berdasarkan uji-t, $\mathrm{p}<0,05$ signifikan, $\mathrm{p}<0,001$ sangat bermakna 0 : sebelum tindakan anestesi, 1 : satu menit setelah tindakan anestesi, 9:9 menit setelah tindakan anestesi 
Tabel 7 Nilai Rata-rata dan Simpang Baku Laju Nadi (x/menit)

\begin{tabular}{|c|c|c|c|c|c|}
\hline \multirow{3}{*}{$\begin{array}{c}\text { Menit } \\
\text { Ke- }\end{array}$} & \multicolumn{4}{|c|}{ Kelompok } & \multirow{3}{*}{ Nilai $F_{1}$} \\
\hline & \multicolumn{2}{|c|}{ Spinal $(n=35)$} & \multicolumn{2}{|c|}{ Umum $(n=35)$} & \\
\hline & Rata-rata & SB & Rata-rata & SB & \\
\hline 0 & 95,11 & 12,04 & 93,83 & 13,62 & 0,677 \\
\hline 1 & 95,14 & 17,15 & 93,51 & 15,78 & 0,681 \\
\hline 2 & 91,69 & 16,52 & 96,23 & 16,74 & 0,257 \\
\hline 3 & 93,23 & 16,57 & 95,23 & 14,74 & 0,596 \\
\hline 4 & 91,37 & 15,43 & 95,60 & 14,92 & 0,248 \\
\hline 5 & 91,80 & 14,61 & 91,67 & 15,67 & 0,972 \\
\hline 6 & 92,77 & 14,32 & 87,68 & 12,75 & 0,202 \\
\hline 7 & 91,66 & 14,20 & 87,40 & 15,66 & 0,351 \\
\hline 8 & 92,00 & 14,38 & 91,13 & 11,29 & 0,873 \\
\hline 9 & 92,31 & 15,30 & 88,00 & 15,3 & 0,783 \\
\hline
\end{tabular}

Keterangan: nilai p berdasarkan uji-t, $\mathrm{p}<0,05$ bermakna. 0: sebelum tindakan anestesi 1: satu menit setelah tindakan anestesi, 9: sembilan menit setelah tindakan anestesi

terutama diinervasi oleh serabut-serabut saraf simpatis dari $\mathrm{T}_{5}-\mathrm{L}_{1}$ yang mempersarafi otot polos arteri dan vena. Blokade serabut saraf tersebut menyebabkan vasodilatasi pembuluh darah vena, terkumpulnya darah pada bagian bawah (splanik dan juga ekstremitas bawah) dan penurunan aliran darah balik ke jantung. Vasodilatasi arteri mengakibatkan penurunan resistensi vaskular sistemik. Vasodilatasi arteri dikurangi dengan kompensasi vasokonstriksi di atas blokade tersebut. ${ }^{8,12-14}$

Beberapa penelitian menyatakan bahwa insidensi hipotensi setelah tindakan anestesia spinal pada seksio sesarea bervariasi dari 30\% sampai $80 \%$. Pada satu penelitian terhadap pasien seksio sesarea yang dioperasi dengan

Tabel 8 Nilai Saturasi Oksigen Perifer $\left(\mathrm{SpO}_{2}\right)$

\begin{tabular}{|c|c|c|c|c|c|}
\hline \multirow{3}{*}{ Menit } & \multicolumn{4}{|c|}{ Kelompok } & \multirow{3}{*}{ Nilai p } \\
\hline & \multicolumn{2}{|c|}{ Spinal $(n=35)$} & \multicolumn{2}{|c|}{ Umum $(n=35)$} & \\
\hline & Median & Rentang & Median & Rentang & \\
\hline 0 & 99 & $97-100$ & 99 & $98-100$ & 0,822 \\
\hline 1 & 99 & $97-100$ & 99 & $95-100$ & 0,210 \\
\hline 2 & 99 & $95-100$ & 99 & $97-100$ & 0,003 \\
\hline 3 & 99 & $95-100$ & 98 & $96-100$ & 0,001 \\
\hline 4 & 99 & $96-100$ & 98 & $93-100$ & $<0,001$ \\
\hline 5 & 99 & $96-100$ & 98 & $96-100$ & $<0,001$ \\
\hline 6 & 99 & $97-100$ & 98 & $96-100$ & $<0,001$ \\
\hline 7 & 99 & $97-100$ & 98 & $98-100$ & $<0,001$ \\
\hline 8 & 99 & $97-100$ & 98,5 & $96-100$ & 0,033 \\
\hline 9 & 99 & $97-100$ & 98 & $97-100$ & 0,129 \\
\hline
\end{tabular}

Keterangan: nilai $p$ berdasarkan Uji Mann-Whitney, $p<0,05$ bermakna, sangat signifikan $(p<0,001)$ 


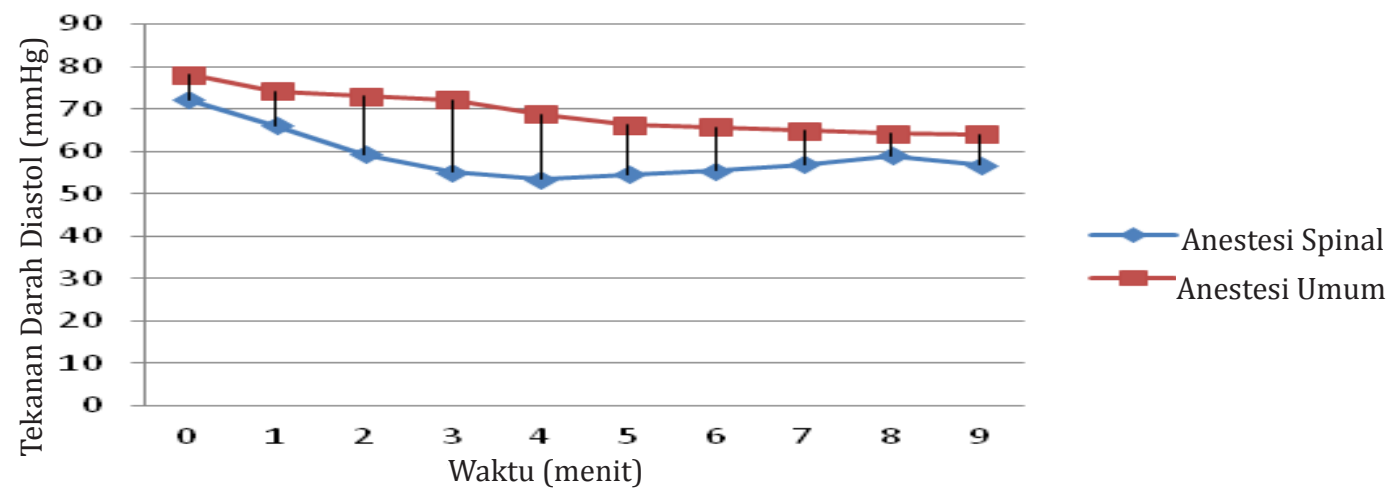

Gambar 2 Tekanan Darah Diastol Rata-rata (mmHg) dari Waktu ke Waktu pada Kelompok Anestesi Spinal dan Anestesi Umum

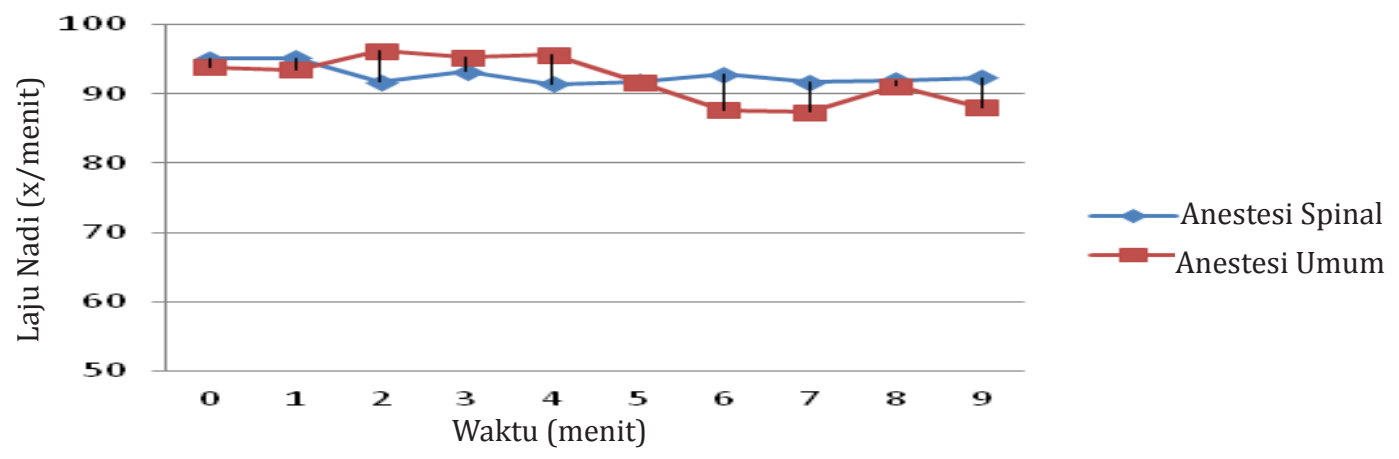

Gambar 3 Perubahan Laju Nadi Rata-rata (x/menit) pada Kelompok Anestesi Spinal dan Anestesi Umum

teknik anestesi umum, tidak didapatkan angka kejadian hipotensi pada saat induksi, intubasi, insisi maupun pada saat pengeluaran bayi. ${ }^{15}$

Hipotensi yang terjadi bila tidak ditangani segera akan menurunkan aliran darah uterus yang berpengaruh terhadap janin sehingga dapat mengakibatkan depresi neonatus yang dapat dinilai dengan mengukur nilai $\mathrm{pH}$ arteri umbilikal serta nilai APGAR bayi. ${ }^{16}$ Berbagai metode telah dilakukan untuk mencegah serta menangani kejadian hipotensi pada seksio sesarea, seperti posisi miring kiri yang secara rutin dilakukan, pemberian cairan preloading intravena yang dapat dilakukan dengan cairan kristaloid atau koloid, elevasi tungkai bawah, penekanan tungkai bawah memakai stocking, penggunaan vasopresor (efedrin, fenilefrin, atau, mefenteramin).

Incision delivery interval pada kelompok anestesia spinal adalah $16,89(3,70)$ menit dan kelompok anestesia umum 6,14 $(1,51)$ menit. Perbedaan tersebut disebabkan karena drapping pada kelompok perlakuan anestesia spinal dilakukan saat setelah penyuntikan obat spinal yang memerlukan waktu, sedangkan pada kelompok anestesia umum induksi baru dilakukan setelah drapping serta operator siap memulai operasi sehingga interval ID menjadi lebih pendek.

Interval ID dihubungkan dengan keadaan neonatus pada saat lahir. Pada anestesi umum bila interval ID lebih dari 8 menit dihubungkan dengan penurunan yang bermakna $\mathrm{pH}$ darah arteri umbilikalis, asidosis neonatal yang akan menurunkan nilai APGAR. ${ }^{5,8,17}$ Keuntungan anestesi umum adalah kecepatan waktu dalam induksi, keadaan ini dapat dilihat dari interval ID yang pendek yaitu rata-rata 6 menit. Pada 
anestesia spinal, pemanjangan interval ID yang tidak disertai hipotensi tidak memengaruhi nilai APGAR dan status asam basa bayi. ${ }^{11,17}$

Uterine incision deliveryinterval (UD) untuk kelompok anestesia spinal pada penelitian ini adalah 105,11 $(63,19)$ detik, sedangkan pada kelompok anestesia umum ialah 96,74 $(42,84)$ detik. Berdasarkan hasil analisis statistika tidak terdapat perbedaan signifikan di antara kedua kelompok $(\mathrm{p}=0,769)$. Waktu UD Interval yang lebih dari 180 detik dihubungkan dengan nilai APGAR yang lebih rendah disebabkan gangguan aliran darah uteroplasental. ${ }^{18}$ Suatu penelitian menyatakan bahwa pada anestesia umum terdapat hubungan yang positif antara waktu insisi uterus sampai pengeluaran bayi dan angka kejadian asidosis bayi bila interval UD lebih dari 90 detik. $^{19}$

Kelebihan anestesia umum adalah interval ID yang pendek, oleh karena itu diindikasikan untuk kasus dengan kecepatan waktu menjadi faktor utama misalnya keadaan gawat janin..$^{4-7}$ Nilai APGAR bayi yang ditemukan oleh Virginia Apgar, merupakan suatu sistem penilaian yang mudah dilakukan, dan juga merupakan sebuah metode sederhana yang secara cepat menilai kondisi kesehatan bayi yang baru lahir sesaat setelah kelahiran..$^{20}$ Skor ini ditujukan untuk mengidentifikasi bayi-bayi yang memerlukan resusitasi dan menindaklanjuti perkembangan berikutnya pada saat menit-menit pertama kehidupan. ${ }^{8,21,22}$ Nilai APGAR $\geq 7$ menyatakan bahwa bayi berada dalam kondisi yang baik. ${ }^{23}$

Berdasarkan pembagian secara kategori/ klinis pada nilai APGAR 1 menit didapatkan 28/35 subjek pada nilai 8-10 untuk kelompok anestesia spinal, sedangkan untuk kelompok anestesia umum didapatkan nilai APGAR 5-7 pada 25/35 subjek. Berdasarkan uji statistika didapatkan perbedaan yang bermakna secara klinis $(\mathrm{p}<0,005)$, yaitu nilai APGAR 1 menit lebih tinggi pada kelompok anestesia spinal, sedangkan nilai APGAR 5 menit pada kedua kelompok didapatkan persentase yang sama $(p=1)$ sehingga tidak terdapat perbedaan nilai APGAR 5 menit pada kedua kelompok.

Pada anestesia umum, sebagian besar obat yang dipergunakan (sedasi dan juga analgetik) memiliki berat molekul serta derajat ionisasi rendah, kelarutan dalam lemak tinggi, dan juga terikat pada protein secara tidak sempurna sehingga dapat memasuki barier plasenta dan berefek pada bayi. Depresi pada janin akan berbatas apabila waktu dari induksi anestesi sampai kelahiran berjalan kurang dari 8 menit, keadaan ini dapat dilakukan dengan menunda saat induksi hingga tindakan drapping selesai dilakukan, dan operator sudah siap memulai tindakan pembedahan. ${ }^{5,6,8,17}$ Kebutuhan obat pada tindakan anestesia spinal sangat sedikit sehingga pengaruh pada bayi dapat diabaikan.

Pada nilai APGAR 1 menit dari kelompok anestesi umum didapatkan $25 / 35$ bayi dengan asfiksia ringan (nilai APGAR 5-7), sedangkan pada kelompok anestesia spinal didapatkan $7 / 35$ bayi. Bayi dengan keadaan asfiksia ringan membutuhkan tindakan medis segera seperti penyedotan lendir yang menyumbat jalan napas, pemberian oksigen untuk membantu pernapasan, dan juga diberikan stimulasi taktil dengan menggosok ataupun menepuk telapak kakinya. ${ }^{20,21,24}$ Nilai APGAR 1 menit memberi gambaran kemampuan bayi untuk melakukan toleransi terhadap proses kelahiran, dan juga menunjukkan bahwa bayi yang baru lahir ini membutuhkan perhatian medis lebih lanjut, namun belum tentu mengindikasikan akan terjadi masalah jangka panjang, khususnya jika terjadi peningkatan nilai pada menit kelima. ${ }^{20}$

Pada nilai APGAR 5 menit dari kelompok anestesia spinal maupun anestesia umum didapatkan bahwa hampir semua bayi berada dalam kondisi yang baik/normal, dengan nilai APGAR 8-10. Nilai APGAR 5 menitmemberikan penilaian seberapa jauh bayi dapat beradaptasi dengan lingkungannya yang baru, dan juga merupakan indeks yang lebih tepat tentang kemungkinan kematian bayi dan atau sekuele neurologik. ${ }^{25,26}$ Berdasarkan suatu penelitian nilai APGAR 5 menit memperlihatkan kondisi yang baik pada pasien yang mendapat anestesi umum. Hal ini menyatakan bahwa tidak banyak pengaruh dampak jangka panjang pada bayibayi yang dilahirkan dengan anestesi umum tetapi terdapat efek yang signifikan pengaruh teknik anestesia dalam jangka waktu pendek. Efek tersebut kemungkinan besar disebabkan karena pengaruh obat-obatan pada bayi yang 
diberikan pada saat anestesia umum sebelum bayi dilahirkan. ${ }^{19}$ Nilai APGAR 5 menit yang kurang dari 4 merupakan prediktor yang kuat terhadap kematian neonatus. Risiko kematian neonatus pada saat APGAR 5 menit adalah 0,2/1.000 pada bayi dengan nilai APGAR 7-10, sedangkan pada bayi dengan nilai APGAR 0-3 adalah 244/1.000. ${ }^{23}$ Telah dilaporkan risiko yang akan meningkat untuk terjadinya kejang, keterlambatan perkembangan mental, epilepsi, cerebral palsy, perdarahan intrakranial pada nilai APGAR 5 menit di bawah 7.22,27

\section{Simpulan}

Kejadian hipotensi pada anestesia spinal lebih tinggi apabila dibandingkan dengan anestesia umum. Nilai APGAR bayi 1 menit lebih tinggi pada anestesia spinal apabila dibandingkan dengan anestesia umum. Nilai APGAR 5 menit pada anestesia spinal tidak berbeda dengan anestesia umum.

\section{Daftar Pustaka}

1. Afolabi BB, Lesi FEA, Merah NA. Regional versus general anesthesia for cesarean section (Review). The Cochrane Collaboration. 2006;4:1-44.

2. Gori F, Pasqualucci A, Corradetti F, Milli $\mathrm{M}$, Peduto VA. Maternal and neonatal outcome after cesarean section: the impact of anesthesia. J Mat-Fet \& Neon Med. 2007;20:53-7.

3. Algert CS, Bowen JR, Giles WB, Knoblanche GE, Lain SJ, Roberts CL. Regional block versus general anaesthesia for cesarean section and neonatal outcomes: a population-based study. BMC Med. 2009;7:20.

4. Petropoulos G, Siristatidis C, Salamalekis E, Creatsas G. Spinal and epidural versus general anesthesia for elective cesarean section at term: effect on the acid base status of the mother and newborn. J MatFet \& Neon Med. 2003;13:260-6.

5. Stoelting RK, Miller RD. Basics of anesthesia. Edisi ke-4. New York: Churchill
Livingstone Inc; 2000.

6. Birnbach DJ, Browne IM. Anesthesia for obstetrics. Dalam: Miller RD, penyunting. Anesthesia. Edisi ke-6, New York: Churchill Livingstone Inc; 2005. hlm. 2307-26.

7. Birnbach DJ. General anesthesia for cesarean section-who needs it? European Society of Anaesthesiologists, Refresher Course. 2003:165-7.

8. Chesnut DH, Polley LS, Tsen LC, Wong CA. Obstetric anesthesia, principles and practice. Edisi ke-4. Philadelphia: Mosby Elseiver; 2009.

9. Kamat SK, Shah MV, Chaudhary LS, Pandya S, Bhatt MM. Effect of induction-delivery and uterine-delivery on apgar scoring of the newborn. J Post Graduate Med. 1991;37:125-7.

10. Krishnan L, Gunasekaran N, Bhaskaranand N. Neonatal effects of anesthesia for caesarean section. Indian J Pediat. 1995;62:109-13.

11. Terence T, Lao MB, Arthur PC. Fetal condition at caesarean section and type of anaesthesia. J Hong Kong Medical Association. 1997;39(3):163-4.

12. Bernard CM. Epidural and spinal anesthesia. Dalam: Barash PG, Cullen BF, Stoelting RK, penyunting. Clinical anesthesia. Edisi ke-5. Philadelphia: Lippincott Williams \& Wilkins; 2006. hlm. 691-710.

13. Strichastz GR. Neural physiology and local anesthetic action. Dalam: Cousins MJ, Bridenbaugh PO, penyunting. Neural blockade. Edisi ke-3. Philadelphia: Lippincot-Ravin Co; 1998. hlm. 35-52.

14. Vikram MS, Harsoor SS. Spinal anesthesia with low dose bupivacaine with fentanyl for cesarean section. SAARC J Anesth. 2008;1(2):142-5.

15. Kamat S, Gupta R, Raju M. Prevention of hypotention following spinal anesthesia for cesarean section: comparison between crystalloid preloading \& prophylactic ephedrine bolus \& infusion (diunduh 26 Februari 2011). Tersedia dari: http:// www./iskarnataka.in. 
16. Valami HM, Jahromi HA, Shirazi J, Mohammadi N. Comparison of effect of spinal anesthesia between pre-eclamptic patients and normal pregnant women during cesarean section. Pak J Med. 2010;26(4):809-13.

17. Datta S. Obstetric anesthesia handbook. Edisi ke-4. USA: Springer; 2006.

18. Morgan EG, Mikhail MS, Murray MJ. Clinical anesthesiology. Edisi ke-4. New York: McGraw-Hill Companies; 2006.

19. Sukhera AS, Ahmed S. Neonatal outcome; a comparison between epidural and general anesthesia for cesarean sections. Professional Med J. 2006;13(1):72-8.

20. Skor APGAR (diunduh 27 Februari 2011). Tersedia dari: http://id.wikipedia org/ wiki.

21. Cohen SE, Levinson G, Shnider SM. Evaluation of neonate. Dalam: Shnider SM, Levinson G, penyunting. Anesthesia for obstetric. Edisi ke-3. Baltimore: Williams \& Wilkins; 1993. hlm. 671-92.

22. Chong M, Yip P, Kalberg J. APGAR score and postnatal outcomes. J Paediatr Obstetr Gynaecol. 2002:1-8.

23. Casey MB, Mcintire DD, Leveno JK. The continuing value of the APGAR score for the asssessesment of newborn infants. $\mathrm{N}$ Engl J Med. 2001;344(7):467-71.

24. Goffman D, Bernstein P. The effect of anesthesia on APGAR score (diunduh 27 Februari 2011). Tersedia dari: http:// www.medscape.com.

25. Behrman ER, Vaghan CV. Ilmu kesehatan anak: Nelson. Edisi ke-14. Jakarta: EGC Penerbit Buku Kedokteran; 1998.

26. Menilik skor APGAR (diunduh 27 Februari 2011). Tersedia dari: http://catatan .legawa.com/2011/02.

27. Ehrenstein V, Pedersen L, Grijota M, Nielsen LG, Rothman JK, Sorensen TH. Association of APGAR score at five minutes with long-term neurologic disability and cognitive function in a prevalence study of Danish conscripts. BMC Pregnancy and Childbirth. 2009;9(14):1-7. 